 \\ UF $\mid$ FLORIIDA \\ IFAS Extension
}

\section{Keeping it Clean: A Healthy House ${ }^{1}$}

\section{Mary N. Harrison ${ }^{2}$}

The way you keep your home will affect the health of your family and especially of your children. The number of children with asthma is increasing. You can help make your home a safe and healthy place for your children by eliminating or controlling the risks outlined in this publication.

\section{Dust and Dust Mites}

Dust mites are too small to be seen, but are found in most homes. They live in mattresses, pillows, carpets, fabric-covered furniture, bedding, and stuffed toys. To control them:

- Use dust proof or plastic zippered covers over the mattresses and pillows.

- Wash sheets and bedding once a week.

- Keep childrens stuffed toys clean, wash them often.

- Use hard floors if given a choice. If carpets are used, vacuum them daily in areas where children play and weekly in other areas. (Remember children are often on the floor near carpets and dust.)

\section{Pets}

Your pets' urine, skin flakes, hair,and saliva can trigger asthma and other allergies.

- Keep pets out of the bedroom and other sleeping areas. Keep them off beds and furniture where children sleep.

- Keep pets clean. Bathe them often.

- If practical keep pets out-of-doors.

- Keep pets' bedding clean.

\section{Molds}

Mold and mildew trigger respiratory problems. The key to mildew and mold control is moisture control.

- Wash mold/mildew off hard surfaces.

- Fix leaky faucets and other water supply systems.

- Keep drip pans in air conditioners and refrigerators clean and dry.

1. This document is FCS5232-01, one of a series of the Family Youth and Community Sciences Department, Florida Cooperative Extension Service, Institute of Food and Agricultural Sciences, University of Florida. Original publication date June 2002. Revised December 2006. Visit the EDIS Web Site at http://edis.ifas.ufl.edu.

2. Mary N. Harrison, professor, Department of Family, Youth and Community Sciences, Cooperative Extension Service, Institute of Food and Agricultural Sciences, University of Florida, Gainesville, 32611.

The Institute of Food and Agricultural Sciences (IFAS) is an Equal Opportunity Institution authorized to provide research, educational information and other services only to individuals and institutions that function with non-discrimination with respect to race, creed, color, religion, age, disability, sex, sexual orientation, marital status, national origin, political opinions or affiliations. U.S. Department of Agriculture, Cooperative Extension Service, University of Florida, IFAS, Florida A. \& M. University Cooperative Extension Program, and Boards of County Commissioners Cooperating. Larry Arrington, Dean 
- Use exhaust fans in the kitchen and bathrooms when bathing, cooking, or using the dishwasher.

- Keep clothing, furnishings, and bathroom dry.

\section{Pests}

Droppings and body parts of pests such as cockroaches and rodents create health problems.

- Do not leave food or garbage out.

- Store food in airtight containers.

- Clean up all spilled crumbs and liquids immediately.

- Try using boric acid for roaches and traps or poison bait for other insects.

- If sprays must be used, follow instructions on the label.

- Be careful to use insecticides and sprays on infected areas only and avoid breathing them.

\section{Paint}

Paint sometimes peels and is unattractive. It can also be dangerous. If the paint is old (used in the 1970s or earlier) it may contain lead. Extreme care should be used to remove old paint and its dust. If children eat paint chips or breathe dust from lead based paint they can get lead poisoning which will affect them mentally.

\section{Secondhand Smoke}

Research has proven that children and others can be affected by breathing secondhand smoke from cigarettes, pipes, and cigars. Anyone who smokes should do it outside the home and away from others.

\section{Household Products}

Special caution should be made to store cleaning supplies and medicines where they are out of reach of children. Common household products can be toxic for children and can poison them.
Remember: A healthy family—a healthy home. 